\title{
Színkülönbség-érzékelő képesség mérése és fejlesztése középiskolás tanulók körében
}

\section{Measuring and developing color aptitude of students at high schools}

\author{
E. PERGE \\ Debreceni Egyetem, Műszaki Kar, Műszaki Alaptárgyi Tanszék \\ perge@eng.unideb.hu
}

Absztrakt. A “Színérzékelés” címü foglalkozás a Debreceni Egyetem „Debrecen Venture Catapult"címü EFOP-3.6.116-2016-00022 számú projektje keretében valósul meg. A foglalkozás célja a tanulók színérzékelési képességének, valamint a színekkel történő kommunikációs képességnek a fejlesztése. Programunkat a müszaki felsőoktatásban potenciálisan továbbtanuló középiskolások számára ajánljuk. Ebben a cikkben bemutatásra kerül a középiskolát végzett tanulók világosságkülönbség-érzékelő képességének és a telítettségkülönbség-érzékelö képességének mérési eredménye, valamint a kutatás részét képezö, a képességfejlesztéshez kidolgozott eszközök és azok alkalmazási módjai.

Abstract. The tutoring project called "Chromatic sensation" will be executed via the project of the University of Debrecen titled EFOP-3.6.1-16-2016-00022 „Debrecen Venture Catapult". The aim of this tutoring project is to develop the students' sense of colour and their ability to communicate through the use of colours. Our project is recommended to high-school students who might want to engage their further education in the fields of engineering. This paper presents the results of our research where ability to sense brightness differences and saturation differences of students completed their high school studies were tested, and discusses our skill development tools and their applications as an integrated part of our research.

\section{Bevezetés}

A színérzékelés fejlődésével kapcsolatos kutatások, kísérletek egyre nagyobb ütemben, és egyre nagyobb számban figyelhetők meg napjainkban. Részletesen ismerjük a színlátás genetikai és molekuláris mechanizmusát, valamint azt az evolúciós folyamatot, mely lehetővé teszi a különböző színárnyalatok megkülönböztetését [1,2,3,7]. Ezek mellett a színlátással, érzékeléssel való problémák, hiányosságok is jelen vannak.

Az alap- és középfokú intézményekben az oktatási tevékenységünk részfeladata a fiatalok felkészítése egy olyan világra, melyet a színek uralnak, a színes természeti és épített környezet, színes tárgyak, színes képek, a színes plakátok, a nyomtatott színes dokumentumok, a színes filmek... A színelméleti ismeretek megismerése, elsajátítása, alkotó alkalmazása ma Magyarországon az alap- és középfokú 
intézményekben a Nemzeti alaptanterv alapján számos tantárgy (rajz, fizika, kémia, biológia, művészettörténet és informatika) oktatásának keretében valósul meg [4], melyre később a szakmai képzés épít.

A tapasztalatunk szerint a középiskolát végzett fiatalok körében a színtani ismeretek alkalmazásának képessége általában igen alacsony szintű [5]. A nem megfelelő színlátás Magyarországon több mint 100 foglalkozás esetében korlátozó, vagy kizáró tényező lehet [9,10]. Korunkban egyre több munkatevékenységnél szükség van a jó színlátásra. A színtévesztés kényszeríthet arra fiatalokat, hogy nem megfelelően megválasztott tanulmányait, megálmodott hivatását, esetleg a meglévő foglalkozását feladja. Sok szakmában például a képzőművészetben, az iparművészetben, az építészetben, a marketingben, a látvány-, kiadvány- és terméktervezésben, az élelmiszer-, a közlekedés-, az autó-, a textil-, a festék- és a kozmetikai iparban, valamint a termékgyártás minden ágazatában a munka fontos eleme a létrehozott tárgyak, termékek, terek megfelelő színvilágának kialakítása.

Megfelelően jó színlátók között bizonyos szakmák munkafolyamatainak a végzéséhez előnyt jelent a színérzékelés, ill. a színkülönbség-érzékelés képességének magas foka. Az ehhez kapcsolódó mérnöki, művészeti és egyéb szakmai képzésekben ezért nagy hangsúlyt kell fektetni a színelméleti ismeretek elsajátítására és az ismeretek alkotó alkalmazásához szükséges képességek fejlesztésére, mert ezek hiánya gátolja a magas színvonalú munkavégzést [6,8].

Annak érdekében, hogy a középiskolát végzett fiatalok felkészültebbek legyenek a pályaválasztás tekintetében, célom a project futamideje alatt a műszaki felsőoktatásban továbbtanuló középiskolások tájékozottságának és növelése és a szakmavégzéshez szükséges készségek fejlesztése.

\section{Foglalkozások bemutatása}

Kutatási tevékenységem a Színérzékelés témakör tartalmi elemének kidolgozására, valamint a képesség fejlesztés módszereinek és eszközeinek a kidolgozása irányul. Fejlesztő módszerünk egyik célja a hallgatók színkülönbség-érzékelő képességének fejlesztése,

Kutatási tevékenységem részeként egy felmérést végeztem középiskolát végzett tanulók körében a szín-megkülönböztető képességükről, majd a foglalkozásokon alkalmazható fejlesztő módszert dolgoztam ki a szín-megkülönböztető képesség fejlesztésére. Meghatároztam a foglalkozások programját, részletes tematikáját, a képességfejlesztéshez használt eszközöket terveztem és hoztam létre, majd a foglalkozásokon alkalmaztam azokat.

Középiskolás korosztály számára olyan módszer került kidolgozásra, mely néhány órás, élményekben gazdag foglalkozás keretében irányítja rá a figyelmet a színtani ismeretek fontosságára és hasznosságára, és felhívja a figyelmet azokra az eszközökre, melyeket a tanulók az alkotó munkájuk végzéséhez szükséges képességeik (színérzékenységük, színmeghatározó-, színmegkülönböztetőképességük) fejlesztésére alkalmazni tudnak.

A színtani ismeretek és készségek fejlesztésére kidolgozott módszerünket debreceni középiskolások körében alkalmaztuk. 
A foglalkozások normál és rendhagyó tanórákon, valamint, szakkörök, speciális iskolai programok keretében valósultak meg. Egy foglalkozás időtartalma $3 \times 45$ perc.

\section{Középiskolát végzett tanulók színkülönbség-érzékelő képessége}

A kutatás egyik eleme a középiskolát végzett hallgatók színérzékelő képességének felmérése. A színek három fố tulajdonsága a színezet, a világosság és a telítettség. A kutatási vizsgálat annak eldöntésére irányult, hogy különböző színezetek esetén, milyen a tanulók világosságkülönbség- ill. telítettségkülönbség-érzékelő képessége.

A mérést 2018 szeptemberében végeztük, a Debreceni Egyetem Műszaki Karán tanulmányait megkezdő 176 hallgató részvételével, melyből 140 fiú és 36 leány. Ebben a fejezetben a mérési eredményeket mutatjuk be.

\subsection{Világosságkülönbség-érzékelő képesség mérése}

A vizsgálatban azonos színezetű és azonos telítettségű, de különböző világosságú színmintákat kellett összehasonlítani. A teszt tanulónként $49 \mathrm{db}$ színpárosítást tartalmaz a világossági értékek összehasonlításában. Válaszként azt kellett megmondani, hogy a színpárok azonos világosságúak vagy nem.

A tanulók világosságkülönbség-érzékelő képessége a magenta és a cián színezet esetén volt a legpontosabb, a tanulók 79\% ill. 76\% tudta helyesen megkülönböztetni az azonos színezetű és azonos telítettségű, de különböző világosságú mintákat. Ezt követte a narancs, a kék, a piros és a sárga színezetek esetében a 68,67, 65 és a 63\%-os tanulói teljesítmény. Vizsgálataink alapján legkevésbé érzékelték a világosságkülönbséget a zöld (57\%) színezet esetében (2.1. ábra).

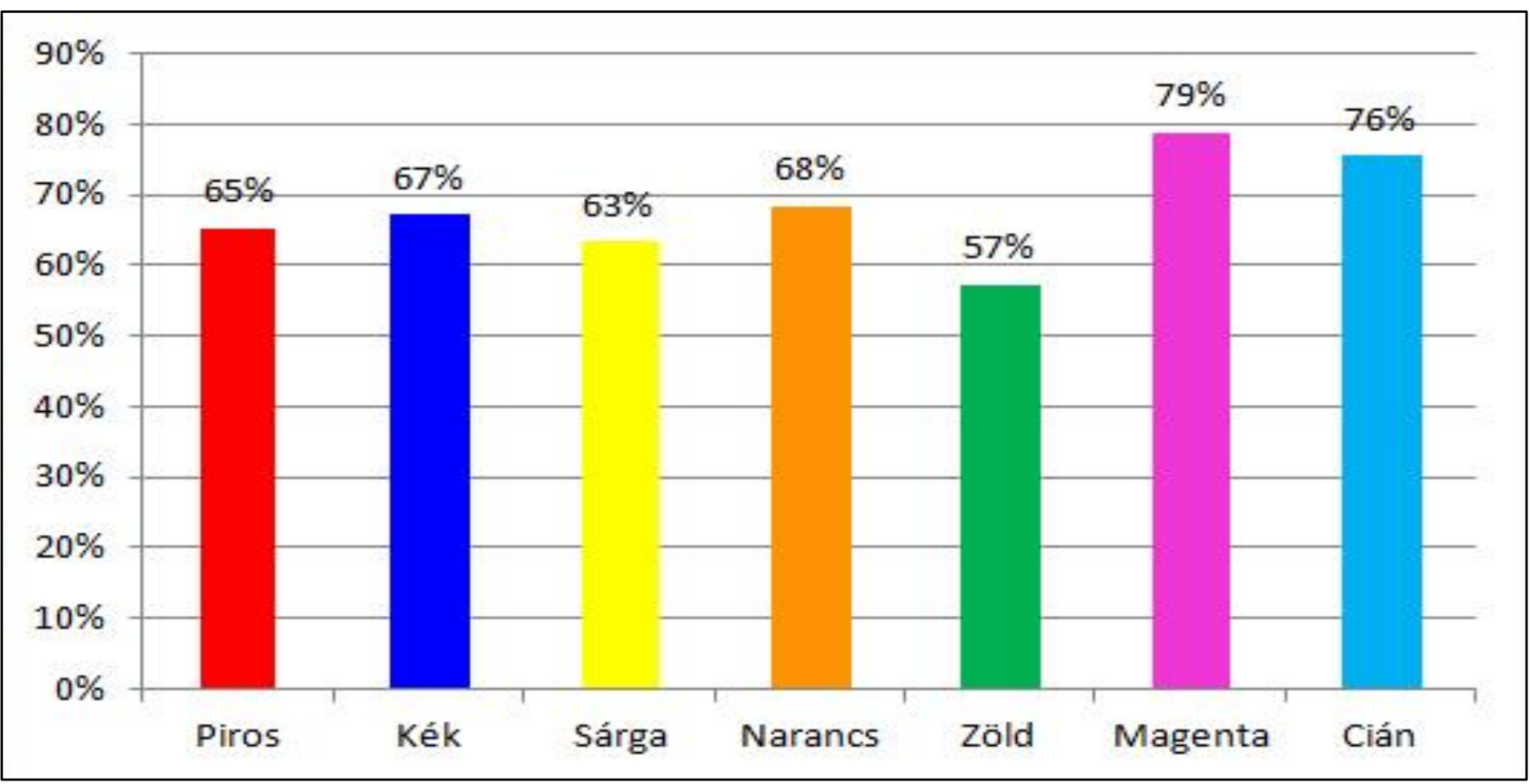

2.1. ábra. Tanulók világosságkülönbség-érzékelésének teljesítménye különbözô színezetek esetén 
Vizsgálatunk kiterjedt a férfiak és a nők teljesítményének összehasonlítására. Világosságkülönbségérzékelés tekintetében a különböző nemek teljesítményében különbség nagyon kis mértékben (1\%), vagy egyáltalán nem érzékelhető. A sárga színezet esetén nincs különbség, a többi színezet esetén 1\%os teljesítménykülönbség figyelhető meg. A leányok jobban teljesítettek a zöld, a piros, a narancs, és a cián színezet esetében, a férfi hallgatók eredményesebbek a kék és a magenta esetében (2.2. ábra).

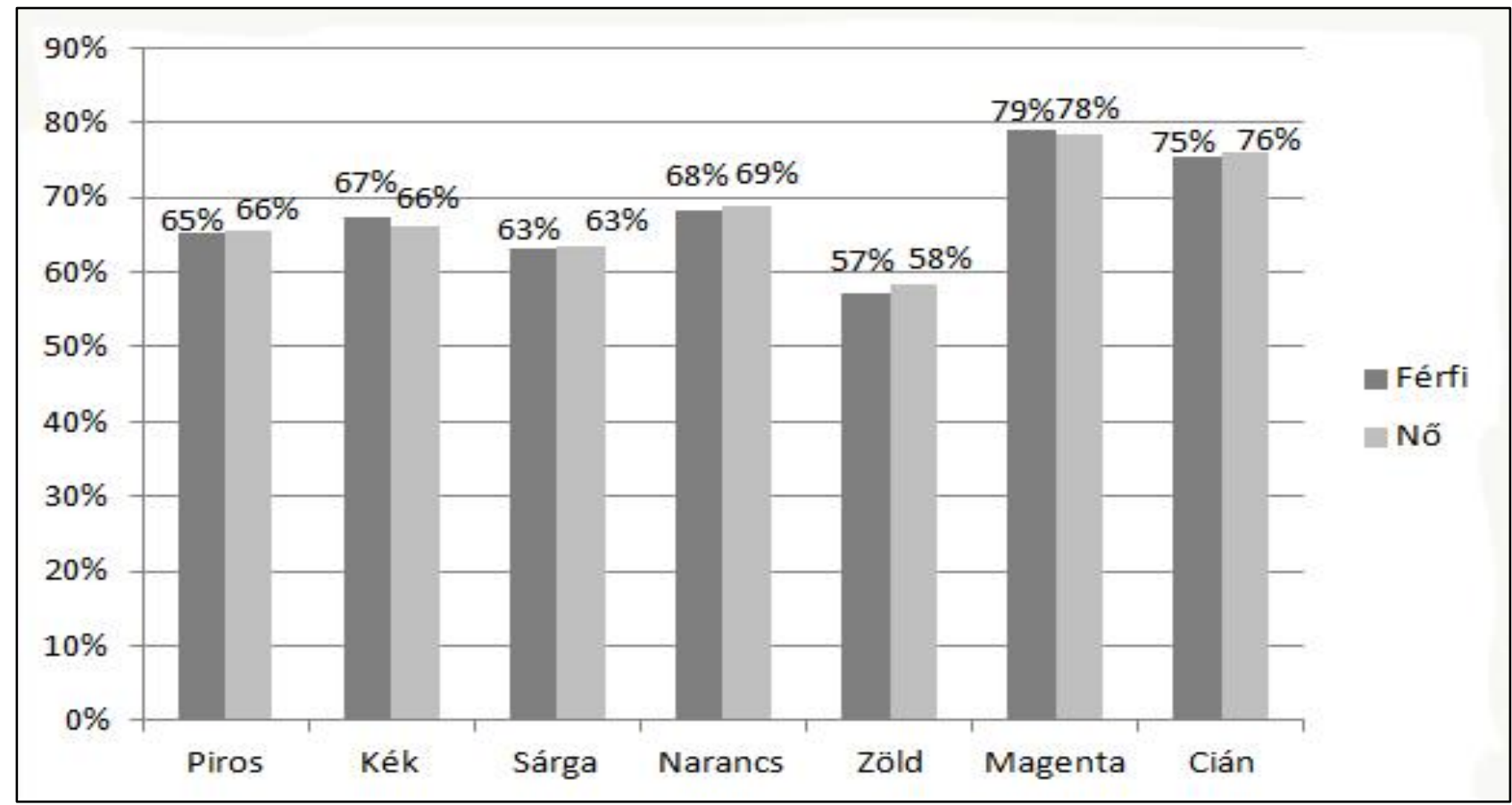

2.2. ábra. Férfiak és nök világosságkülönbség-érzékelésének teljesítménye különböző színezetek esetén

\subsection{Telítettségkülönbség-érzékelő képesség mérése}

A vizsgálatban azonos színezetű és azonos világosságú, de különböző telítettségű színmintákat kellett összehasonlítani. A teszt tanulónként $49 \mathrm{db}$ színpárosítást tartalmaz a telítettségi értékek összehasonlításában. Válaszként azt kellett megmondani, hogy a színpárok azonos telítettségűek vagy nem. 


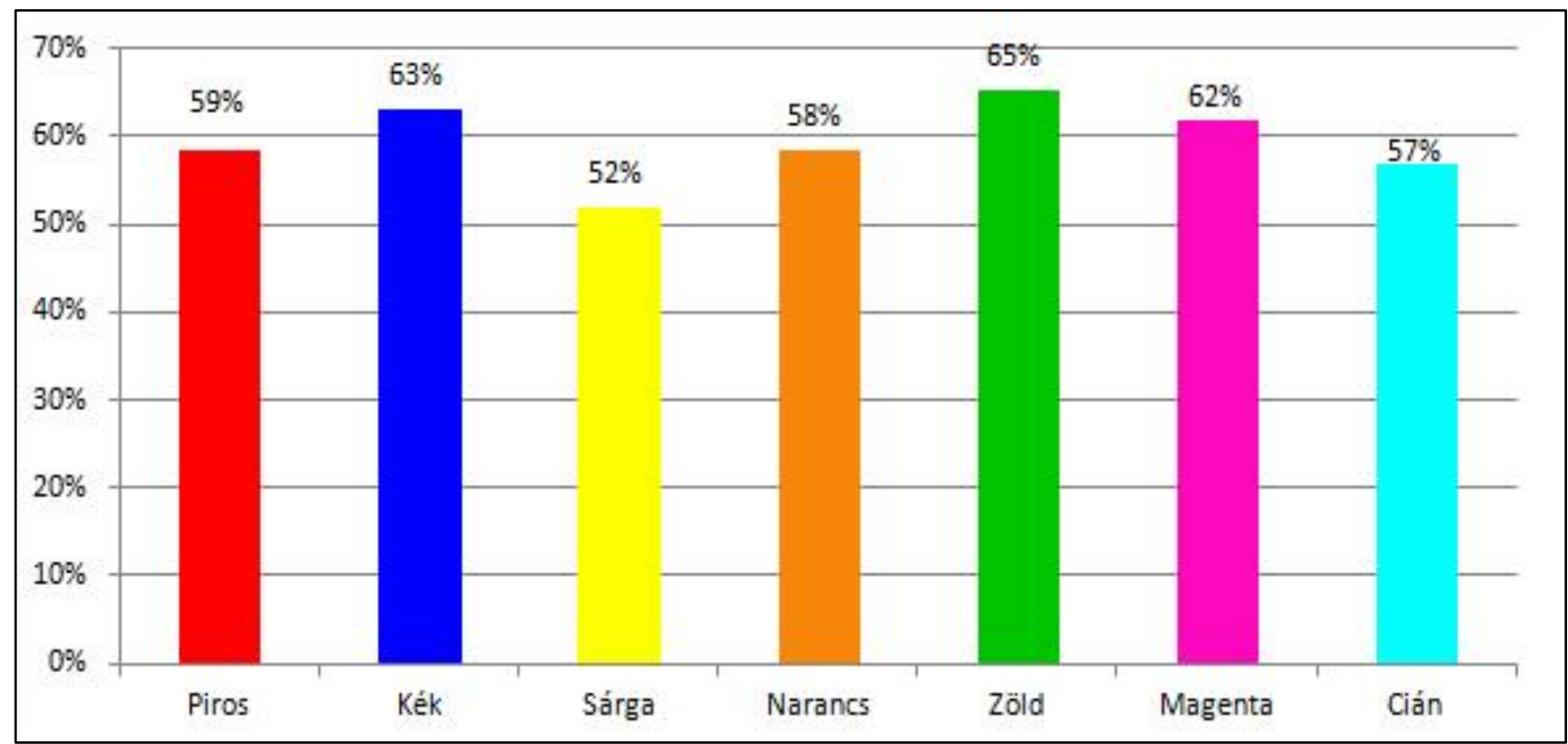

2.3. ábra. Tanulók telítettségkülönbség-érzékelésének teljesítménye különböző színezetek esetén

A tanulók telítettségkülönbség-érzékelő képessége nem mutat jelentős különbséget a különböző színezetek esetében. A tanulók teljesítménye a szín telítettségkülönbség érzékelésében a zöld színezet esetén $65 \%$, a kék esetében $63 \%$, a magenta $62 \%$, a piros $59 \%$, a cián $57 \%$, a narancs $58 \%$, a sárga esetében pedig csak 52\%-os (2.3. ábra).

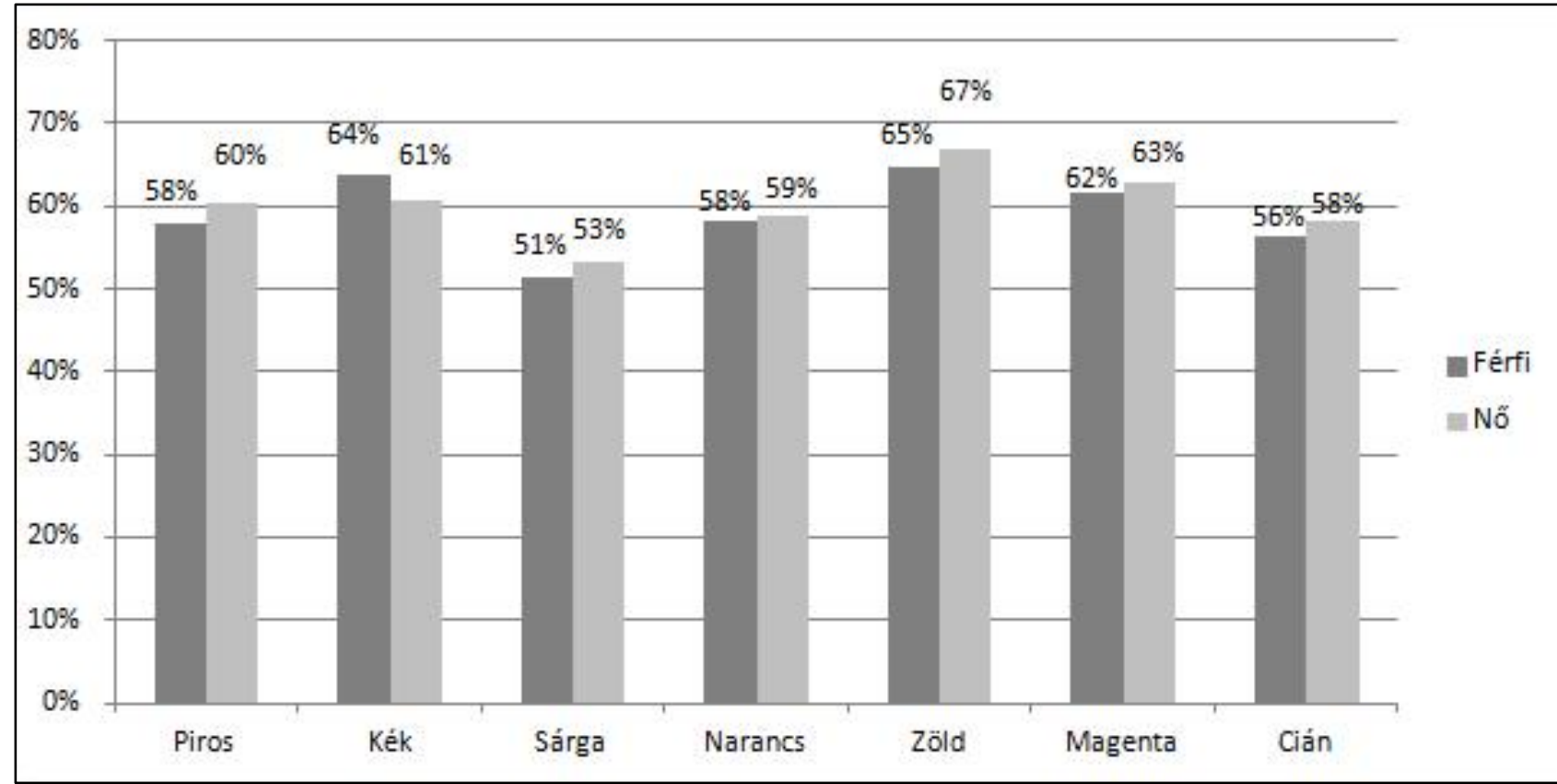

2.4. ábra. Férfiak és nôk telítettségkülönbség-érzékelésének teljesítménye különböző színezetek esetén

Vizsgálatunk kiterjedt a férfiak és a nők teljesítményének összehasonlítására. A telítettségkülönbségérzékelés tekintetében jelentős különbség nem érzékelhető (1-3\%) a különböző nemek 
teljesítményében (2.4. ábra). A kék színezet esetében a férfiak 64\%-a, míg a nők 61\% érzékelte jól a telítettségkülönbséget. Minden más esetben a nők teljesítménye volt jobb, de csak 1-2\%-kal.

\section{Tanulók színkülönbség-érzékelő képességének a fejlesztését támogató eszközök}

A színtani ismeretek és készségek fejlesztését célzó kutatás egyrészt az alkalmazható eszközök kifejlesztésére, másrészt ezek kontrollált körülmények közti alkalmazására irányul.

A foglalkozásokon a színhasonlító feladatokhoz vagy a színgyűjtemények készítéséhez a festékkel szemben előnyben részesítjük a nyomtatott színes kártyákat. A színes kártyák a színek színezet, telítettségi és világossági értékének széles skálájának közvetlen felhasználására ad lehetőséget, amennyiben sokféle kártyánk van, valamint többször is használhatjuk ugyanazt a kártyát, anélkül, hogy szín tulajdonságai vagy felületi adottságai akár egy árnyalatnyit is változnának.

Ebben a részben bemutatjuk a fő feladattípusokat, melyeket színes, nyomtatott kártyákkal valósítottuk meg a foglalkozásokon.

Fejlesztő módszerünk egyik célja a hallgatók színkülönbség-érzékelő képességének fejlesztése, Célunk, hogy a hallgatók képesek legyenek kis különbségek érzékelésére is színezet, telítettség, világosság tekintetében az ehhez kapcsolódó színhasonlító feladatok rendszeres végzésével.

A színkülönbség érzékelés fejlesztése a világosságkülönbség- és a telítettségkülönbség-érzékelés fejlesztésére irányult az alábbi feladattípusok alkalmazásával.

Az egyik feladattípus az

- azonos színezetű - azonos telítettségű - különböző világosságú,

- különböző színezetű- azonos telítettségű - különböző világosságú,

- azonos színezetű - azonos világosságú - különböző telítettségű,

- különböző színezetű - azonos világosságú - különböző telítettségű,

- azonos színezetű - különböző telítettségű - különböző világosságú

színminták összehasonlítása.

Másik feladattípus sorba rendezni a színmintákat világosság vagy telítettség szerint csökkenő vagy emelkedő sorrendben.

\subsection{A világosságkülönbség érzékelés fejlesztése}

\subsubsection{Színminták hasonlítása}

Feladat: Adott $17 \mathrm{db}$ azonos színezetû, azonos telítettségű, de különböző világosságú színminta, összekeverve, leforgatva (3.1. ábra). Minden minta mérete $5 \times 10 \mathrm{~cm}$. Húzz két mintát és döntsd el, melyik a világosabb! 

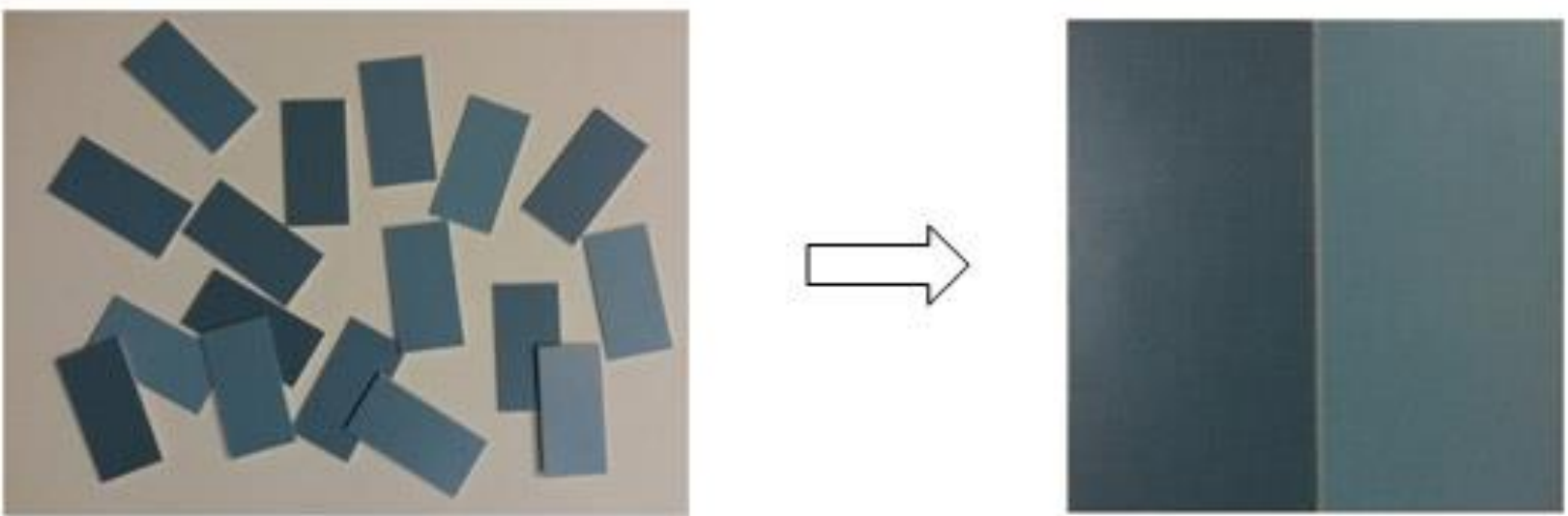

3.1. ábra. Különböző világosságú mintapár választása

A minták véletlenszerű választásával a két minta világosság értékének különbsége változó lesz. Előfordul, hogy csak nagyon kicsi a különbség a két minta között (nehéz a feladat), de az is előfordulhat, hogy nagy a különbség (könnyű a feladat).

A feladat nehézségét lehet fokozni:

- a kiadott mintasorral (a feladat egyre nehezebb, ha a 17 tagú mintasorban az egymást követő színminták világosság értékének a különbsége egyre kevesebb),

- a színminták összehasonlításakor a minták nem érintkezhetnek.

\subsubsection{Színminták sorba rendezése}

Feladat: Adott 17 db azonos színezetű, azonos telítettségű, de különböző világosságú színminta, összekeverve (3.2. ábra). Minden minta mérete $5 \times 10 \mathrm{~cm}$. Rakd sorba a színmintákat a legvilágosabbtól a legsötétebbig!

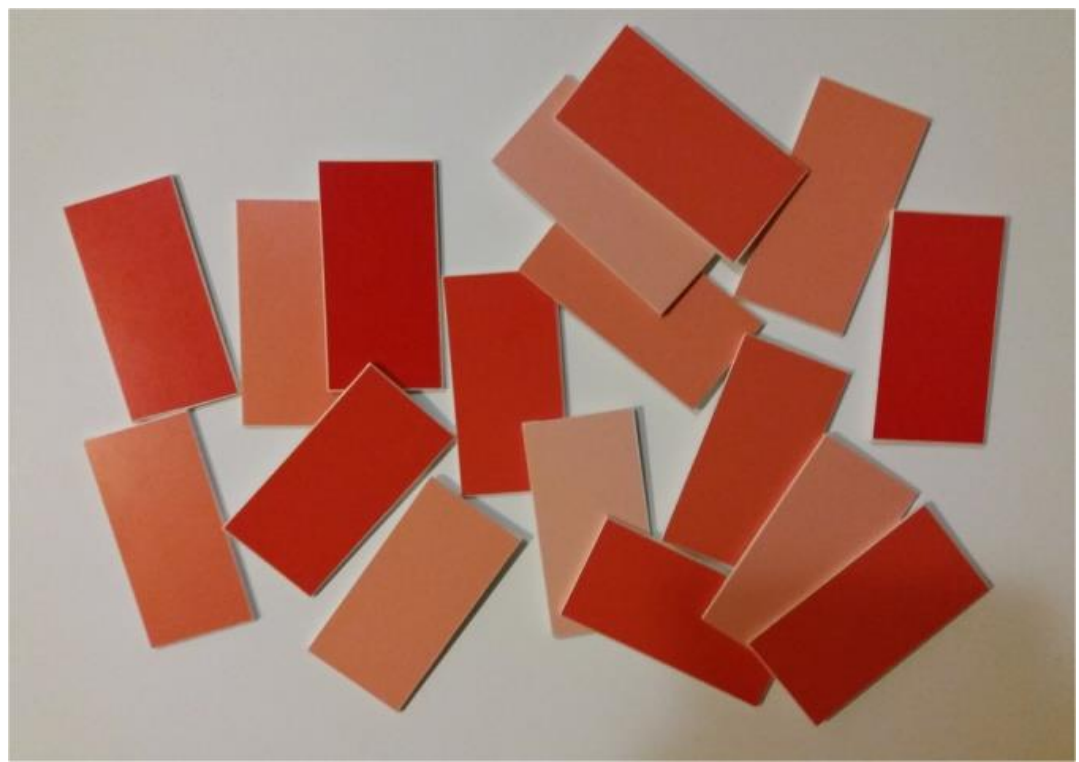

3.2. ábra. Különböző világosságú színminták

A színminták elhelyezésére egy fehér keretet használunk fekete vagy szürke mélyedéssel. 


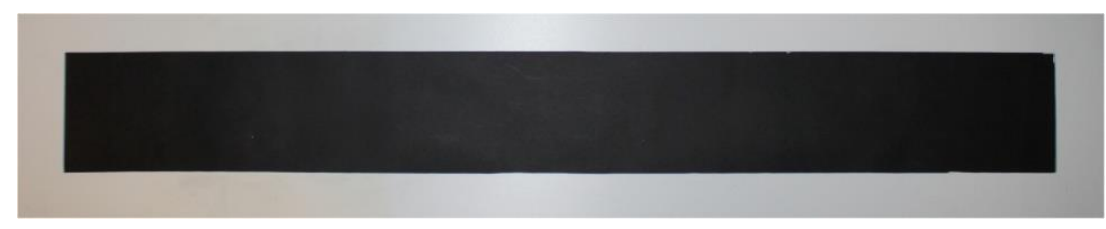

3.3. ábra. Színmintákat befoglaló keret fekete mélyedéssel

A feladat nehézségét lehet fokozni:

- a kiadott mintasorral (a feladat egyre nehezebb, ha a mintasorban az egymást követő színminták világosság értékének a különbsége egyre kevesebb),

- a minták elhelyezésének módjával (nehezebb a feladat, ha a mintaelemek nem érhetnek össze).

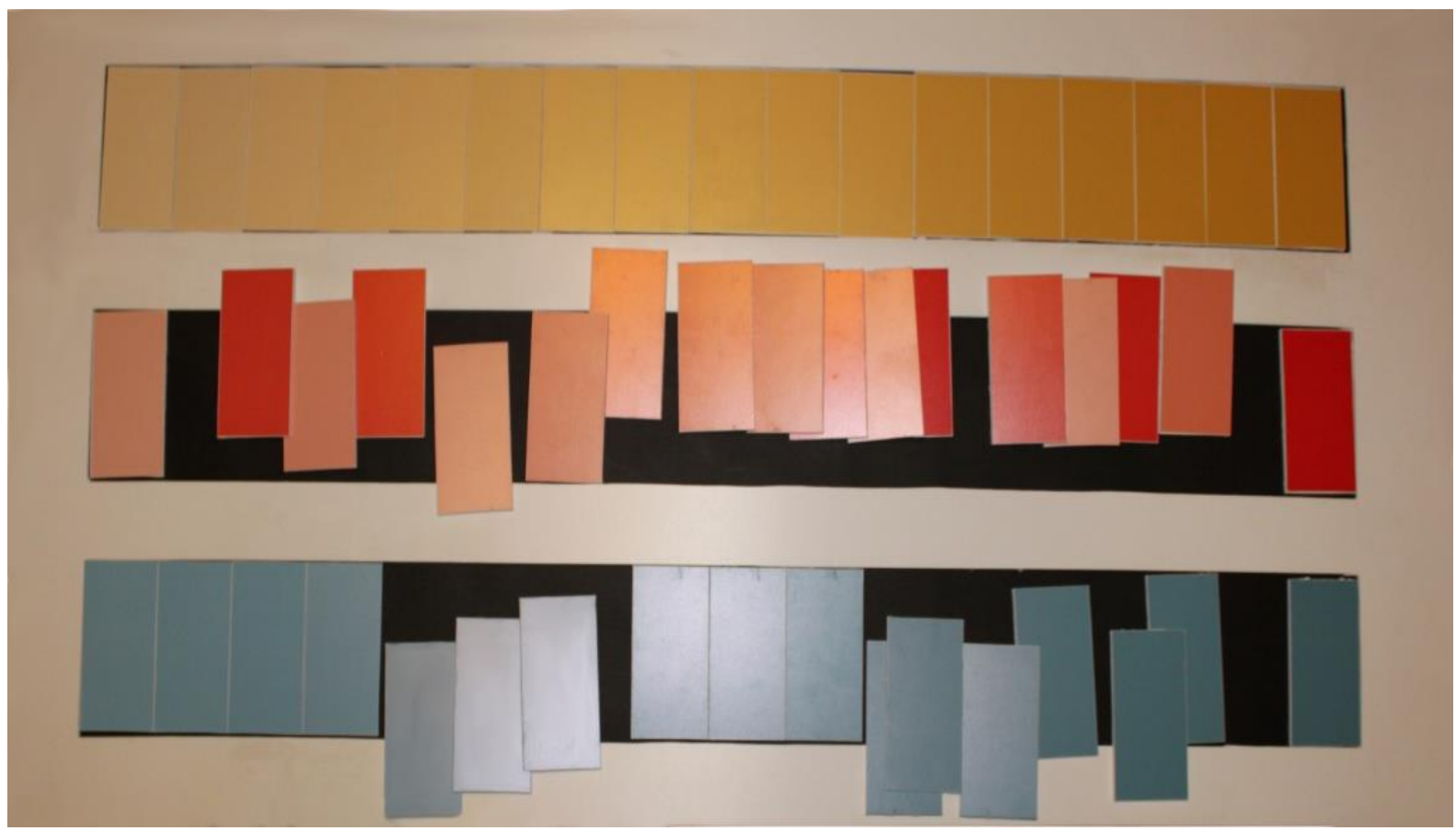

3.4. ábra. Különböző világosságú színminták sorba rendezve háromsoros keretben

\subsubsection{Színminták párosítása}

Feladat: Adottak különböző színezetű és különböző világosságú színminták, valamint ezekkel megegyező világosságú szürkeárnyalatos párjaik (3.5. ábra). Párosítsd össze a különböző világosságú színmintákat a szürkeárnyalatos mintákkal úgy, hogy azok világossági értéke azonos legyen (3.6. ábra)! Méret 7x7 cm. 


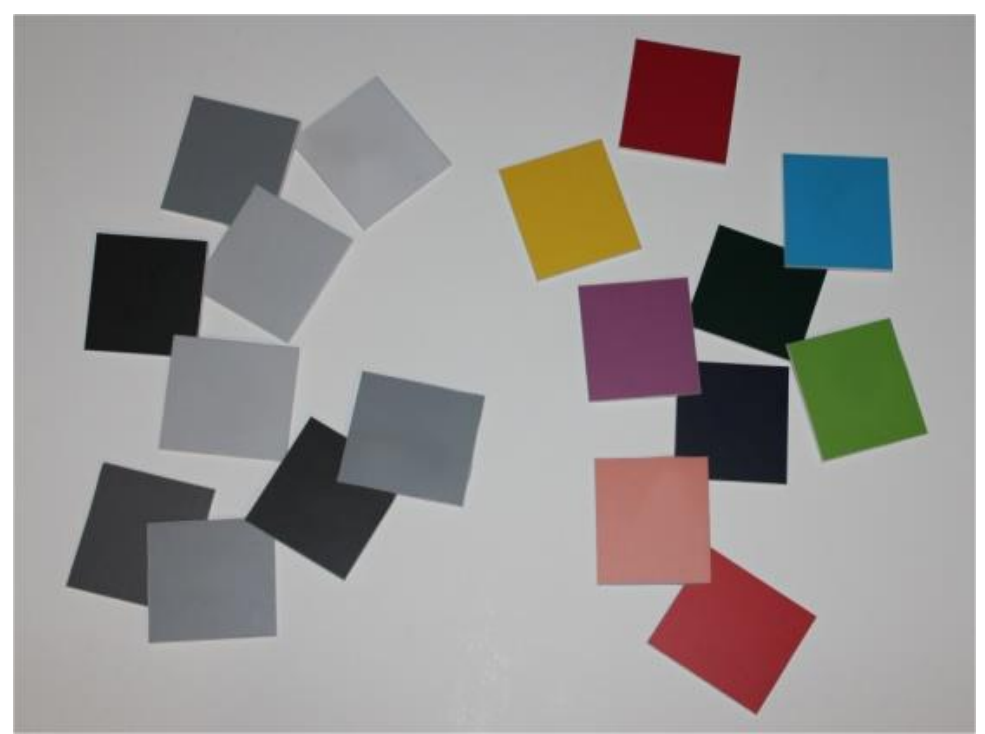

3.5. ábra. Színes és szürkeárnyalatos színminta párok

A feladat nehézségét lehet fokozni a kiadott mintasorral és azok párjaival, színes minták közötti egyre kisebb világosságkülönbséggel.

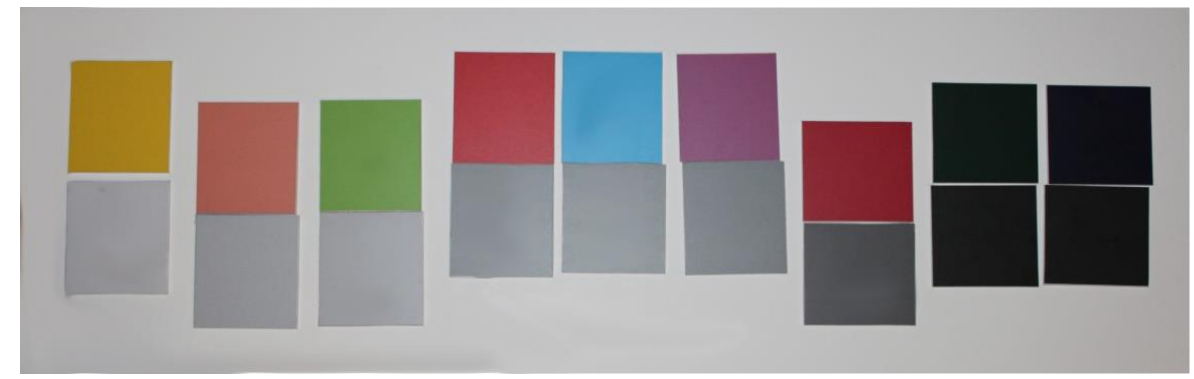

3.6. ábra. Színes és szürkeárnyalatos színminták párosítása

\subsubsection{Párosítás szürkeskála elemeihez}

Feladat: A fehértől a feketéig terjedő 7 tagú szürkeskálán helyezd el a különböző színmintákat a világossági értéküknek megfelelően! Minta mérete 10x15 cm.
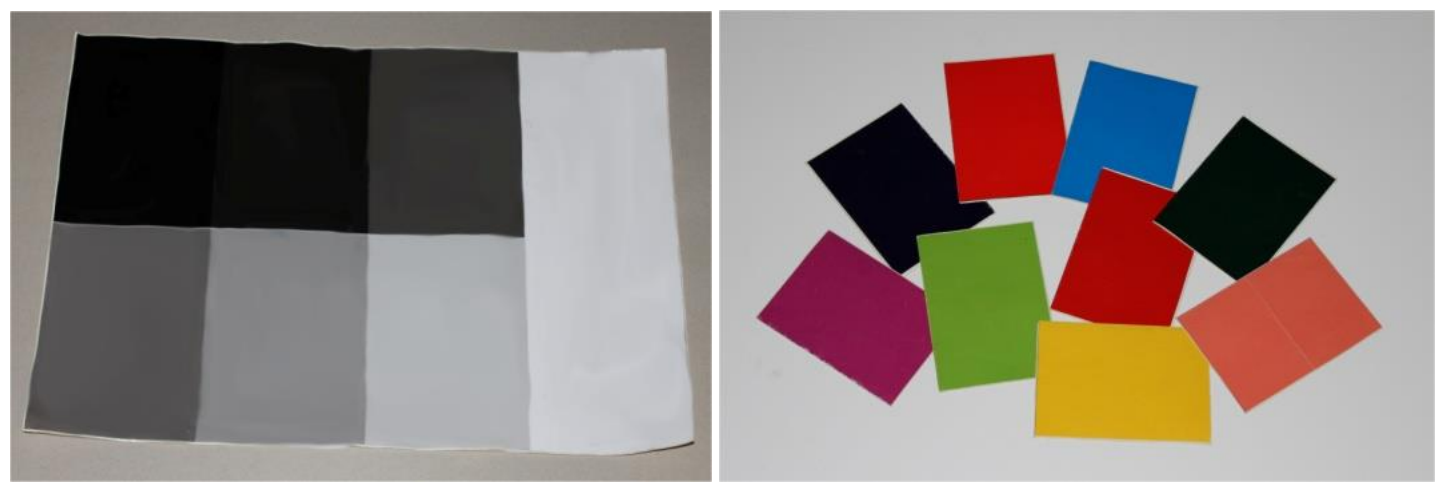

3.7. ábra. Szürkeskála színmintákkal

A feladat nehézségét lehet fokozni a kiadott mintasorral, ha azonos szinezetű mintákról áttérünk különböző színezetű minták alkalmazására. 

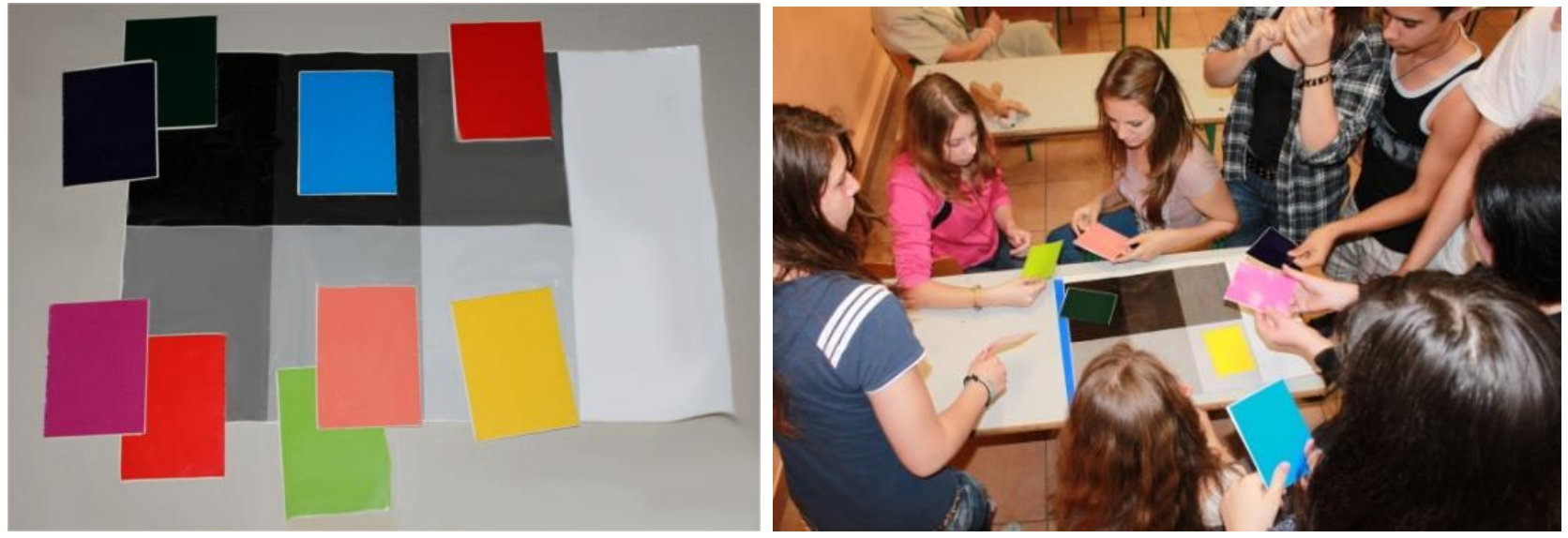

3.8. ábra. Színminták elhelyezése a szürkeskálán

\subsection{A telítettségkülönbség-érzékelés fejlesztése}

\subsubsection{Színminták hasonlítása}

Feladat: Adott 17 db, azonos színezetű, azonos világosságú, de különböző telítettségű színminta, összekeverve, leforgatva. Minden minta mérete $5 \times 10 \mathrm{~cm}$ Húzz két mintát és döntsd el, melyik a telítettebb!
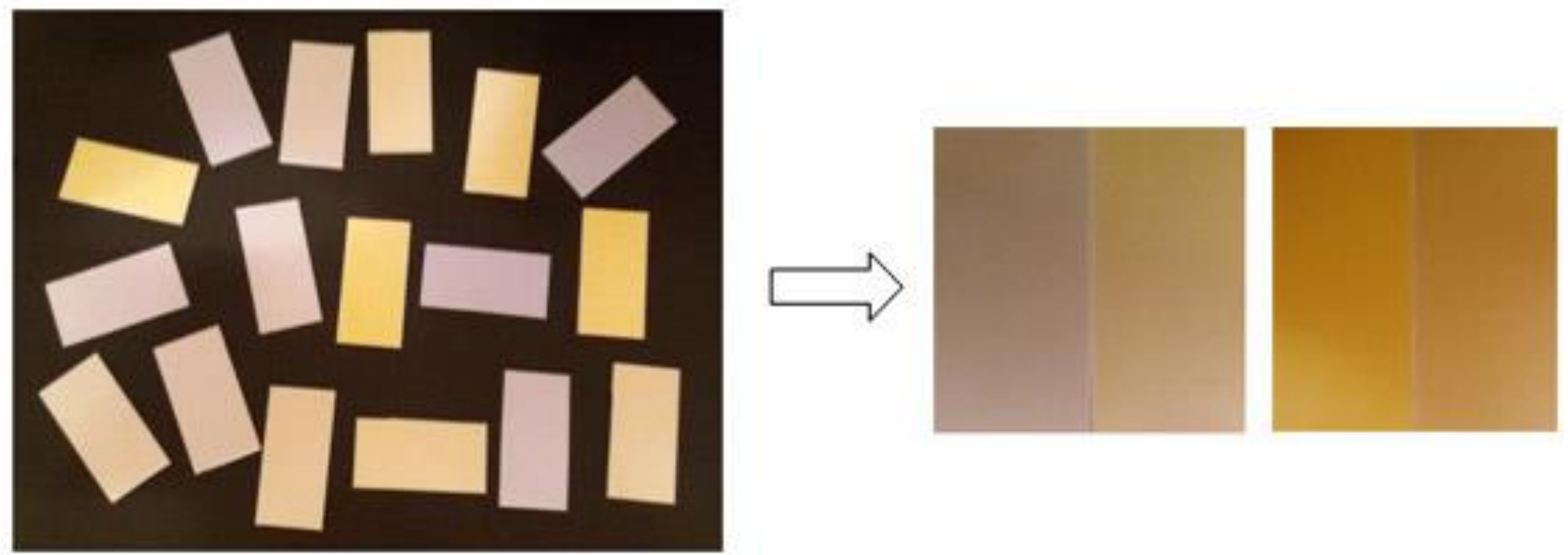

3.9. ábra. Különböző telítettségű mintapár választása

A minták véletlenszerű választásával a két minta telítettség értékének a különbsége változó lesz. Előfordul, hogy csak nagyon kicsi a különbség a két minta között (nehéz a feladat), de az is előfordulhat, hogy nagy a különbség (könnyű a feladat).

A feladat nehézségét lehet fokozni a kiadott mintasorral. A feladat egyre nehezebb, ha a 17 tagú mintasorban az egymást követő színminták telítettség értékének a különbsége egyre kevesebb.

\subsubsection{Színminták sorba rendezése}

Feladat: Adott 17 db, azonos színezetű, azonos világosságú, de különböző telítettségű színminta, összekeverve. Minden minta mérete $5 \times 10 \mathrm{~cm}$. Rakd sorba a mintákat a legtelítettebbtől a legtelítetlenebbig! 


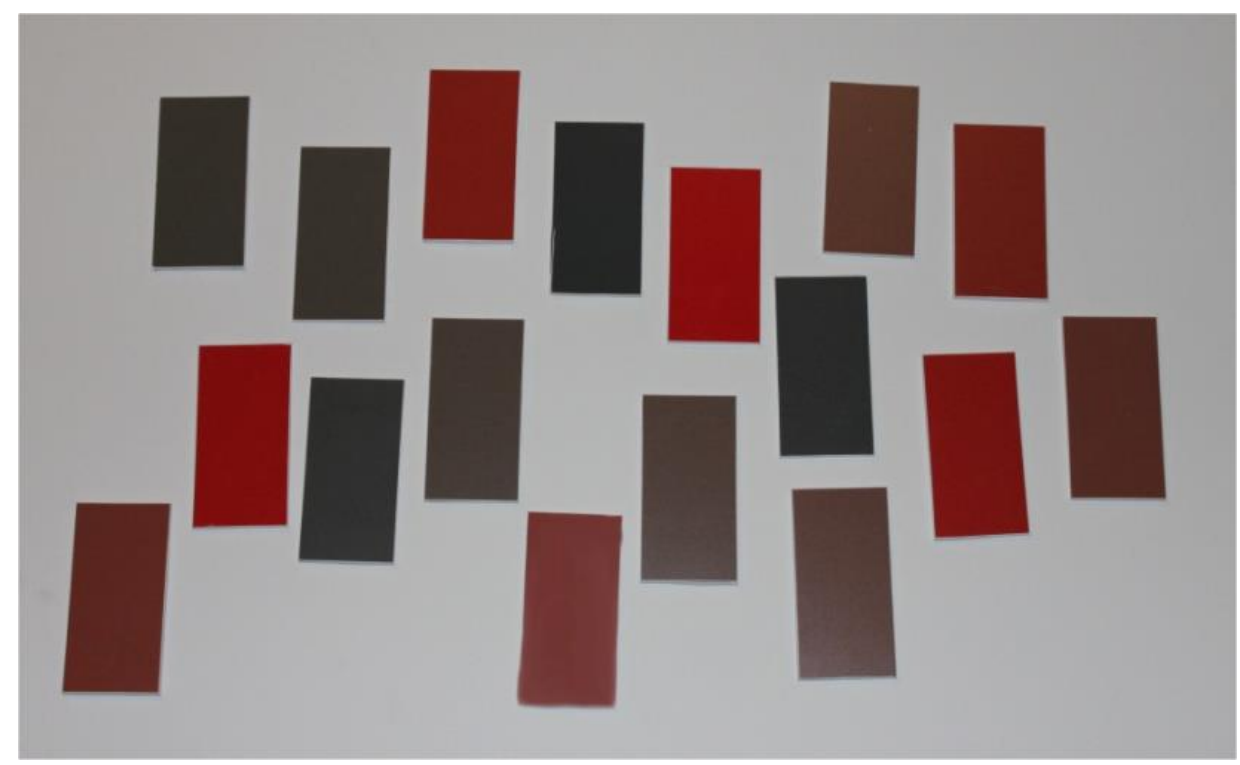

3.10. ábra. Különböző telítettségú színminták

A feladat nehézségét lehet fokozni:

- a kiadott mintasorral (a feladat egyre nehezebb, ha a 17 tagú mintasorban az egymást követő színminták telítettség értékének a különbsége egyre kevesebb),

- a minták elhelyezésének módjával (a mintaelemek nem érhetnek össze).

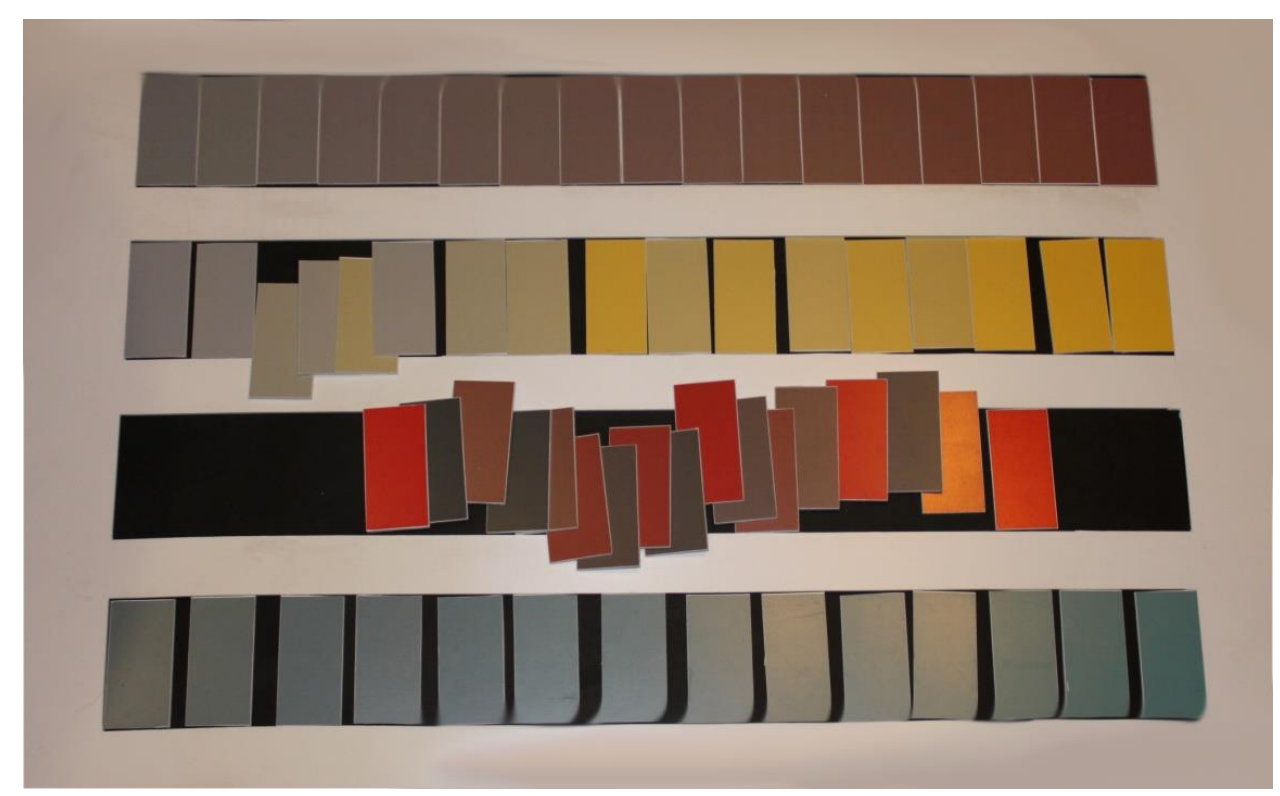

3.11. ábra. Különbözô telítettségú színminták sorba rendezve

\subsection{Világosságkülönbség- és telítettségkülönbség-érzékelés fejlesztése}

\subsubsection{Színminták rendezése}

Feladat: Adott 25 db azonos színezetű, különböző telítettségű, de különböző világosságú színminta, összekeverve. Rendezd el a színmintákat 5x5-os elrendezésben úgy, hogy a világosak legyenek a legfelső sorban, a legsötétebbek a legalsó sorban, a legtelítettebbek a jobboldali szélső oszlopban, a legtelítetlenebbek a baloldali szélső oszlopban legyenek. 


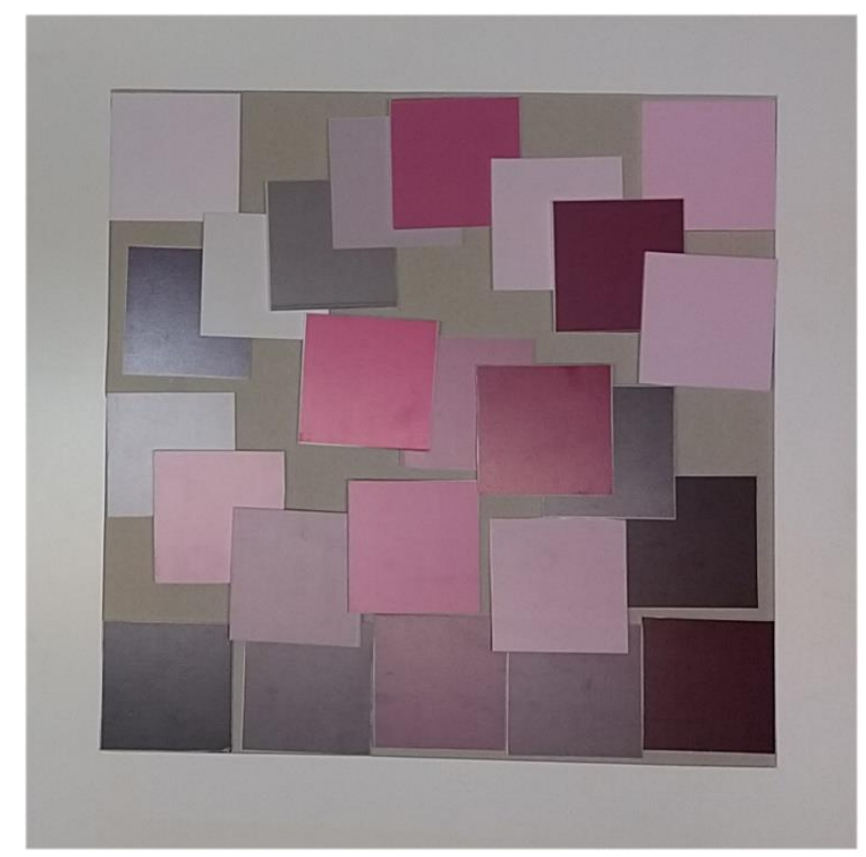

3.12. ábra. Különböző telítettségű és különböző világosságú színminták

A feladat nehézségét lehet fokozni a kiadott 25 elemű mintasorral. A feladat egyre nehezebb, ha a mintasorban az egymást követő színminták világosság értékének és a telítettség értékének a különbsége egyre kisebb.

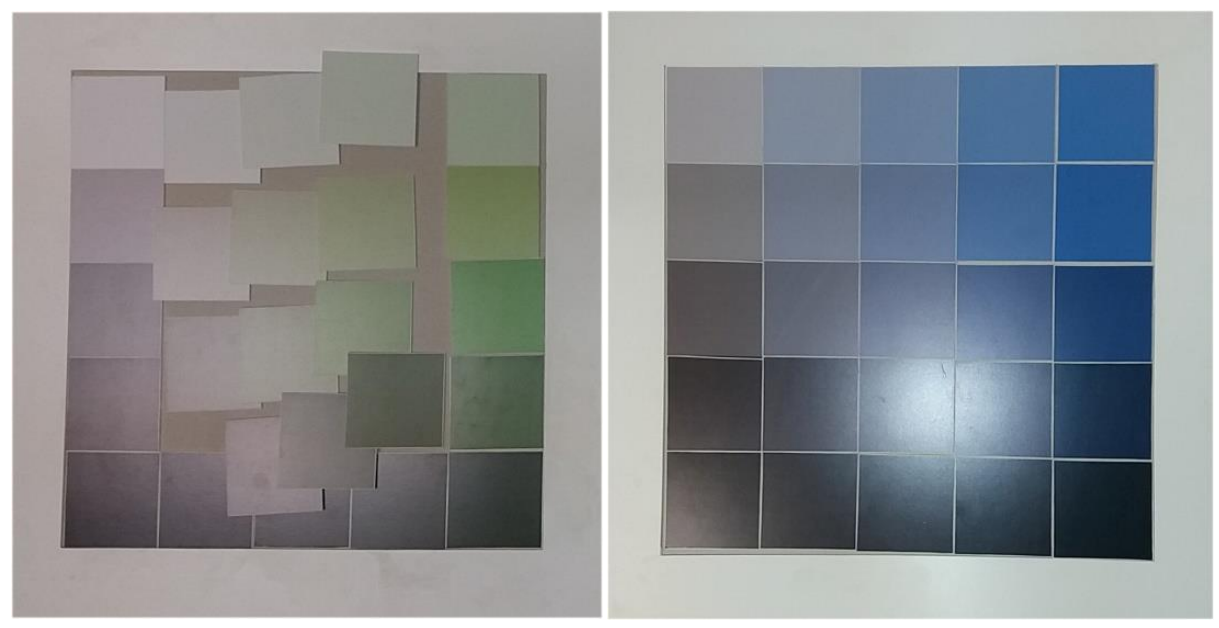

3.13. ábra. Különböző telítettségü és különböző világosságú színminták elrendezése

Színkártyákkal színinger egyeztetésre illetve telítettségi vagy világossági skálák létrehozására annyi kísérlet áll rendelkezésünkre, amennyi feladatot előkészítettünk nyomtatással.

\section{Összegzés}

A “Színérzékelés” címü foglalkozás a Debreceni Egyetem „Debrecen Venture Catapult"címü EFOP-3.6.116-2016-00022 számú projektje keretében valósul meg. Kutatási tevékenységünk célja egy új színoktatási módszer kidolgozása, ezen belül a hallgatók magas színvonalú alkotó- és tervező munkájához szükséges képességeknek az eredményes fejlesztése. 
A foglalkozás célja a tanulók színérzékelési képességének, ezen belül a világosságkülönbség-érzékelő képesség és a telítettségkülönbség-érzékelő képesség fejlesztése. Programunkat a műszaki felsőoktatásban potenciálisan továbbtanuló középiskolások számára ajánljuk.

Ebben a cikkben bemutatásra került a középiskolát végzett tanulók világosságkülönbség-érzékelő képességének és a telítettségkülönbség-érzékelő képességének mérési eredménye, valamint a kutatás részét képező, a képességfejlesztéshez kidolgozott saját fejlesztésű eszközeink és azok alkalmazási módjai.

\section{Köszönetnyilvánítás}

A publikáció elkészítését az EFOP-3.6.1-16-2016-00022 számú projekt támogatta. A projekt az Európai Unió támogatásával, az Európai Szociális Alap társfinanszírozásával valósult meg.

\section{Hivatkozások}

[1] J. Albers (2006) Színek kölcsönhatása, a látás didaktikájának alapjai. Magyar Képzőművészeti Egyetem, Budapest.

[2] R. C. Atkinson - E. Hilgard (2005) Pszichológia. Osiris Kiadó, Budapest, 131-168.

[3] J. W. Goethe (1983) Színtan. didaktikai rész. Johannes Pawlik összeállítása. Fordította: Rajnai László, Művészet és elmélet sorozat. Corvina Kiadó, Budapest.

[4] Nemzeti alaptanterv (NAT)

[5] E. Perge (2015) The experience of applying a method to develop the use of color theory. Annales Mathematicae et Informaticae, 45. pp. 125-149.

[6] E. Perge - M. Zichar (2015) Computer assisted method for cognitive improvement of color aptitude. Proceedings of 6th IEEE Conference on Cognitive Infocommunications. Győr: IEEE, pp. 357-362. ISBN:978-1-4673-8128-4, Konferencia helye, ideje: Győr, 2015.10.19-21.

[7] R. Sekuler - R. Blake (2005) Perception. McGraw-Hill Humanities Publisher, 5 edition, pp.45-122, pp. 205-240.

[8] C. Sik Lányi - Zs. Kosztyán - B. Kránicz - J. Schanda - M. Navvab (2007) Using multimedia interactive e-teaching in color science. LEUKOS The Journal of the Illuminating Engineering Society of North America, 4(1): 71-82. ISSN1550-2724

[9] K. Wenczel (2004) A színtévesztés mérése: a diagnózis. Foglalkozás Egészségügy. 4: 29-34.

[10] K. Wenzel - K. Ladunga - K. Samu (2001) Measurement of color defective and normal color vision subject's color and luminance contrast threshold functions on CRT. Periodica Polytech. 45: 103108. 